\title{
Extreme Phenotypic Plasticity in Metabolic Physiology of Antarctic Demosponges
}

\author{
Simon A. Morley ${ }^{1 *}$, Jade Berman ${ }^{1,2}$, David K. A. Barnes ${ }^{1}$, Carlos de Juan Carbonell ${ }^{1}$, \\ Rachel V. Downey ${ }^{1,3}$ and Lloyd S. Peck ${ }^{1}$ \\ ${ }^{1}$ British Antarctic Survey, Natural Environment Research Council, Cambridge, UK, ${ }^{2}$ Ulster Wildlife, Belfast, UK, \\ ${ }^{3}$ Forschungsinstitut und Naturmuseum Senckenberg, Frankfurt am Main, Germany
}

\section{OPEN ACCESS}

Edited by:

Alberto Basset,

University of Salento, Italy

Reviewed by:

Angel Pérez-Ruzafa,

Universidad de Murcia, Spain

Thanos Dailianis,

Hellenic Centre for Marine Research,

Greece

*Correspondence: Simon A. Morley smor@bas.ac.uk

Specialty section:

This article was submitted to

Marine Ecosystem Ecology,

a section of the journal

Frontiers in Ecology and Evolution

Received: 11 July 2015 Accepted: 31 December 2015

Published: 22 January 2016

Citation:

Morley SA, Berman J, Barnes DKA, de Juan Carbonell C, Downey RV and Peck LS (2016) Extreme Phenotypic Plasticity in Metabolic Physiology of

Antarctic Demosponges.

Front. Ecol. Evol. 3:157.

doi: 10.3389/fevo.2015.00157
Seasonal measurements of the metabolic physiology of four Antarctic demosponges and their associated assemblages, maintained in a flow through aquarium facility, demonstrated one of the largest differences in seasonal strategies between species and their associated sponge communities. The sponge oxygen consumption measured here exhibited both the lowest and highest seasonal changes for any Antarctic species; metabolic rates varied from a $25 \%$ decrease to a 5.8 fold increase from winter to summer, a range which was greater than all 17 Antarctic marine species (encompassing eight phyla) previously investigated and amongst the highest recorded for any marine environment. The differences in nitrogen excretion, metabolic substrate utilization and tissue composition between species were, overall, greater than seasonal changes. The largest seasonal difference in tissue composition was an increase in CHN (Carbon, Hydrogen, and Nitrogen) content in Homaxinella balfourensis, a pioneer species in ice-scour regions, which changed growth form to a twig-like morph in winter. The considerable flexibility in seasonal and metabolic physiology across the Demospongiae likely enables these species to respond to rapid environmental change such as ice-scour, reductions in sea ice cover and ice-shelf collapse in the Polar Regions, shifting the paradigm that polar sponges always live "life in the slow lane." Great phenotypic plasticity in physiology has been linked to differences in symbiotic community composition, and this is likely to be a key factor in the global success of sponges in all marine environments and their dominant role in many climax communities.

Keywords: seasonal physiology, paradigm shift, seasonal metabolism, Porifera, polar physiology, elemental composition, $\mathrm{CHN}$, phenotypic plasticity

\section{INTRODUCTION}

The majority of marine ecosystems are seasonal, with significant annual variation in photoperiod, and temperature leading to variation in food supply (Peck et al., 2006), particularly for suspension feeders. This results in marked reductions in activity, growth, and reproduction of benthic suspension feeders during periods of low food supply (Gruzov, 1977; Hughes, 1989; Fenchel, 1990; Coma et al., 1998). These low food periods largely coincide with the coldest water temperatures and at polar latitudes the seasonal difference in phytoplankton productivity is amongst the highest of any ocean, whilst the shallow water temperature variation is amongst the 
lowest (Venables et al., 2013). Feeding, growth, and reproductive investment of primary consumers are therefore often coupled to the brief austral summer, with reduced feeding and metabolic activity for several months during winter (Gruzov, 1977; Clarke, 1988; Clarke et al., 1988; Morley et al., 2007). Whilst winter dormancy in polar species is common, and can be extreme (e.g., Bryozoan; Barnes and Peck, 2005), in other, even closely related species of suspension feeders, periods of reduced metabolic, and feeding activity can be as short as 1 month (Barnes and Clarke, 1995). The patterns of seasonal physiology are therefore complex and in groups such as carnivores, whose food supply is more consistent throughout the year, physiology is generally less coupled to the overlying seasonality and more closely linked to the timing of key life history events (Clarke et al., 1988; Obermüller et al., 2010).

Sponges are a rich group of sessile invertebrates with over 8500 described species which occur in almost every benthic aquatic habitat (Van Soest et al., 2012). Approximately 400 sponge species have been identified from the Southern Ocean (Janussen and Downey, 2014), where they can be dominant components of Antarctic shelf communities (Dayton et al., 1970, 1974; Voss, 1988; Barthel, 1995). Their high biomass and morphological diversity are believed to be important in maintaining and structuring Antarctic benthic diversity (Gutt and Schickan, 1998; Cocito, 2004; McClintock et al., 2005). The efficient filter feeding of sponges makes them important components of the nutrient cycles of many marine ecosystems (Diaz and Ward, 1997; Diaz and Rutzler, 2001), as they perform an important role in benthopelagic coupling, transferring energy, and carbon from pelagic to benthic ecosystems (Gatti, 2002). Sponges can utilize a variety of food sources, including picoplankton, such as bacteria and viruses within the water column (Hadas et al., 2009; PereaBlázquez et al., 2013a). Despite this wide range of food types, in many environments sponge physiology often varies seasonally with environmental temperature (Fromont, 1994; Witte et al., 1994; Fan and Dai, 1999; Meroz-Fine et al., 2005; Perea-Blazquez et al., 2013b). Growth can also vary seasonally (Harsha et al., 1983) and food availability has been shown to influence seasonal reproductive cycles (Witte, 1996).

Whilst sponges are considered suspension feeders, they are often associated with complex biomes containing bacterial communities which supplement their nutrition (Vacelet, 1971; Wilkinson, 1978; Weisz et al., 2007). These bacterial communities can occupy a large proportion, up to $40 \%$, of the mesohyl volume (Vacelet, 1975; Wilkinson, 1978) and can be a mixture of cyanobacteria or heterotrophic bacterial populations (Wilkinson, 1978) including those that have nitrification (Bayer et al., 2008) or sulfate reduction (Erwin et al., 2012) capacities, which are consistently associated with particular species (Webster et al., 2004). Sponge bacterial symbiont communities can be temporally much more stable than bacteria in seawater (Erwin et al., 2012) and therefore have the potential to limit the seasonal reduction in nutrition that would be expected during the winter months.

This study aimed to evaluate seasonal variation in the physiology of some of the most abundant species of shallow water Antarctic demosponges and their associated communities. Rates of oxygen consumption, nitrogen excretion and body tissue water, ash, and $\mathrm{CHN}$ content were compared between summer and winter. This information is important for understanding the global success of sponges across aquatic habitats, predictions of the capacity of sponge communities to respond to climate change, especially in the Antarctic (Meredith and King, 2005), through environmental warming, reductions in sea ice (Barnes et al., 2014), break up of ice-shelves (Dayton et al., 2013; Fillinger et al., 2013), and any resultant changes in energy flow into the benthic community (Post et al., 2007; Peck et al., 2010; Dayton et al., 2013; Venables et al., 2013).

\section{METHODS}

Species, with differing growth forms, were chosen to represent the dominant demosponge assemblage present in the sublittoral waters around Rothera Research station. No calcareous sponges were collected during subtidal surveys. Only two hexacinellid (glass) sponges were observed during the subtidal surveys and due to their large size they were excluded from this study. Sponges and/or sections of, Axinella antarctica (Koltun, 1964), Calyx arcuarius (Topsent, 1913), Clathria (Axosuberites) nidificata (Kirkpatrick, 1907), Dendrilla antarctica (Topsent, 1905), Hemigellius sp., Homaxinella balfourensis (Ridley and Dendy, 1886), Isodictya kerguelenensis (Ridley and Dendy, 1886), Mycale (Oxymycale) acerata (Kirkpatrick, 1907), Phorbas sp., Sphaerotylus antarcticus (Kirkpatrick, 1907), and Suberites sp., were collected by SCUBA divers from depths of $20-30 \mathrm{~m}$ in Ryder Bay, West Antarctic Peninsula (67 $34^{\prime} \mathrm{S}, 68^{\circ} 07^{\prime} \mathrm{W}$ ). Sponges were maintained in the British Antarctic Survey's flow through aquarium at Rothera Research Station and identified utilizing the standard protocols to examine skeletal architecture and measurement of spicule types (Boury-Esnault and Ruetzler, 1997). Sponges for physiology were cut into approximately equally sized sections, with oscules and ostia present, before being left to recover for at least 1 week so that any increase in metabolic rate caused by regeneration was minimized. Regeneration was considered complete after effective closure of the ectosome by pinacocytes. Sponges were kept in the flow through aquarium system for 12 months and any morphological seasonal variation was recorded qualitatively for each species. Temperature and photoperiod in the aquarium were adjusted to match that of the natural environment, although temperature was approximately $0.2^{\circ} \mathrm{C}$ warmer. Sponges can contain a wide variety of bacteria (Weisz et al., 2008), which may influence metabolic rates (Weisz et al., 2007) and, therefore, the samples were considered as a whole community, including the sponge biome.

The metabolic rate, nitrogenous waste production, and $\mathrm{CHN}$ content of sponge biomes were measured in both summer and winter. Before metabolic rate was measured any visible macroepifauna were carefully removed from the surface of sponges before they were placed in acrylic respirometers. Macrofauna were largely mobile and it was therefore not possible to determine that they were part of the obligate sponge fauna. To reduce the influence of any oxygen production by photosynthetic organisms within the sponge tissue, which would prevent metabolic rate being accurately measured, respirometers were kept in the dark for at least $4 \mathrm{~h}$ before measurements were made. The drop 
in oxygen within each closed cell respirometer was measured using a pre-calibrated Microx-3 oxygen meter (Presens $\mathrm{GmbH}$ ), the needle of which was pushed through a rubber diaphragm sealing the access port of the respirometry chamber. Oxygen consumption trials were run until a $10-20 \%$ drop in oxygen was reached and oxygen concentrations were never allowed to fall below $70 \%$ of saturation. The volume of water in each respirometer was corrected for the volume of sponge, which was calculated by Archimedes principle (the weight of water displaced by the sponge).

After each oxygen consumption trial the water from each respirometer was sub-sampled for measurement of ammonia and urea. All urea samples were frozen and stored at $-80^{\circ} \mathrm{C}$ for later analysis. Most ammonia samples were analyzed immediately, but when necessary, water samples for ammonia analysis were deep frozen with their $\mathrm{pH}$ adjusted twice, once to $\mathrm{pH}<4.5$ before freezing and then to $\mathrm{pH}>7.0$ after defrosting (Degobbis, 1973; Fraser et al., 2002b). Ammonia was assayed with ophthalaldehyde (OPA) fluorometry, using the method as described by Holmes et al. (1999) with minor modifications. In the present study ratios of working reagent (WR) to sample volume ranged between 1:1 and 1:2, compared to 1:4 and 1:0.25 in Holmes et al. (1999). The assay was calibrated by spiking seawater with known amounts of ammonium chloride. All samples and standards were read in a TD700 fluorometer (Turner Designs, California). Ammonia excretion is expressed as $\mu \mathrm{mol} \mathrm{NH} \mathrm{NH}_{3} \mathrm{~h}^{-1} \mathrm{~g}^{-1}$ ash-free dry mass (AFDM). Urea was analyzed using the diacetyl monoxime assay of Rahmatullah and Boyde (1980) with minor modifications according to Fraser et al. (2002b). In the present study, seawater samples were not deproteinized and sample volume and color reagent volume were 1.0 and $0.5 \mathrm{ml}$, respectively. The assay was calibrated by spiking seawater with known amounts of a urea standard solution. All samples and standards were read with a spectrophotometer at $535 \mathrm{~nm}$. Urea excretion rates are expressed as $\mu \mathrm{mol} \mathrm{CO}\left(\mathrm{NH}_{2}\right)_{2} \mathrm{~h}^{-1} \mathrm{~g}^{-1}$ AFDM.

$\mathrm{O}: \mathrm{N}$ ratios (oxygen consumption vs. nitrogen excretion) were calculated on an atomic basis. O: $\mathrm{N}$ ratios can serve as a metabolic index, providing information about proportions of substrate catabolized. Ratios $<20$ indicate mainly protein utilization, whereas ratios of 50-60 suggest more balanced catabolism of protein, lipid, and carbohydrate proportions, and ratios $>100$ indicate a diet dominated by lipids and carbohydrates (Mayzaud and Conover, 1988). Only ammonia-nitrogen was included in calculations of O:N ratios and while this is likely to underestimate total nitrogen excretion, since other products such as urea, primary amines and uric acid all contribute to nitrogenous waste, ammonia is the dominant excretory product of protein catabolism in marine fish and invertebrates (Wood, 1993; Clarke et al., 1994). In invertebrates, excreted urea is likely to be derived from deamination of arginine and/or excretion of purines and pyrimidines, suggesting RNA and nucleic acid breakdown rather than protein metabolism (Baldwin, 1967; Fraser et al., 2002b). Due to time constraints of sampling, not all measures were taken from all species in both seasons.

At the end of each experiment any free water within the sponge matrix was allowed to drain after which the surface was blotted dry. The wet mass, dry mass (DM; constant weight after drying at $60^{\circ} \mathrm{C}$ ) and AFDM (obtained by subtraction of ash remaining from dry mass after $24 \mathrm{~h}$ at $475^{\circ} \mathrm{C}$ ) of each sponge section were then measured. Before samples were ashed, a measured sub-sample of each sponge was removed for total $\mathrm{C}, \mathrm{H}$, and $\mathrm{N}$ measurement. To measure $\mathrm{CHN}$ dry samples were homogenized using a Waring blender and ground to fine powder using a mortar and pestle. All equipment was washed, dried, and cleaned with acetone between samples to minimize contamination. Total $\mathrm{C}, \mathrm{H}$, and $\mathrm{N}$ were measured on powdered sub-samples in a CHN analyser Model CE 440 (Exeter Analytical, Inc., Massachusetts, USA). Sample weights used for analysis typically ranged between 1 and $2 \mathrm{mg}$ DM. Most samples were run once, but random duplicate samples were measured to control assay quality and ensure reproducibility. All runs were carried out with sample blanks (empty tin sample vials), an organic blank (benzoic acid) for nitrogen zeros, and acetanilide standards (quantities dependent on sample size). $\mathrm{CHN}$ data are expressed as percentage of DM (mean \pm standard deviation SD). Proportional data were arcsine square root transformed and other data sets box-cox transformed to normalize residuals from general linear model assessments of differences between species and seasons. For species for which multiple measurements were made within a season, data that were not significantly different were combined.

\section{STATISTICS}

Data were tested for normality with Anderson-Darling tests. Non-normal data were box cox transformed to achieve normality before differences between species and sampling dates were tested with ANOVA followed by post-hoc Tukey tests $(P<0.05)$. In figures and tables significant differences were indicated by an asterisk (ANOVA) and non-significant TUKEY results were indicated by the same lower case letter.

\section{RESULTS}

Water content across sponge species varied from 67 to $95 \%$ (Table 1). There were few differences in water content between seasons but the three species that were significantly different $\left[H\right.$. balfourensis, $F_{(1,28)}=13.9, P<0.01$; S. antarcticus, $F_{(1,42)}=1122, p<0.01$; Suberites sp., $\left.F_{(1,51)}=100, p<0.01\right]$ had lower water content in winter than summer. There were physical differences in the appearance of $H$. balfourensis between the seasons. In winter the morphology was twig-like compared with a more bushy, club form in summer. S. antarcticus also seasonally changed form; in the summer, the oscular papillae were short and stout with wide oscule openings which could contract, whilst in winter these papillae grew long filaments which were closed and had asexual buds along the length (Figure 1). One species, Hemigellius sp. showed a reduction in water content between winter months [June-July, $F_{(1,11)}=5.4$, $P<0.05]$, whilst one species, Suberites sp. showed a reduction in water content between summer months [February-March, $\left.F_{(1,24)}=15.7, P<0.01\right]$. Neither Suberites sp. nor Hemigellius sp. underwent visible morphological changes, however many of the sponges monitored, including Suberites sp. released larvae in October and November (late spring, early summer). 
TABLE 1 | The $\%$ water content of sponge species in summer and winter.

\begin{tabular}{|c|c|c|c|c|c|}
\hline Species & Season & Date & $\% \mathbf{H}_{2} \mathrm{O}$ & SE & $N$ \\
\hline Axinella antarctica & Summer & 12.03 .07 & 84.7 & 1.8 & 3 \\
\hline Axinella antarctica & Winter & 31.07 .06 & 70.9 & 16.0 & 12 \\
\hline Calyx arcuarius & Summer & 06.02 .07 & 81.6 & 0.8 & 8 \\
\hline Calyx arcuarius & Winter & 31.07 .06 & 80.1 & 0.6 & 12 \\
\hline Clathria nidificata & Summer & 20.02 .07 & 86.9 & 0.7 & 11 \\
\hline Clathria nidificata & Winter & 21.07 .06 & 85.9 & 0.4 & 26 \\
\hline Dendrilla antarctica & Summer & 09.02.07-12.03.07 & 86.9 & 0.5 & 36 \\
\hline Dendrilla antarctica & Winter & 09.07.06-19.07.06 & 86.9 & 0.4 & 23 \\
\hline Hemigellius sp. & Winter & 06.06 .06 & $89.1 \mathrm{a}$ & 0.6 & 9 \\
\hline Hemigellius sp. & Winter & 31.07 .06 & $86.3 b$ & 1.1 & 3 \\
\hline $\begin{array}{l}\text { Homaxinella } \\
\text { balfourensis }\end{array}$ & Summer & 06.02 .07 & $79.1^{*}$ & 1.0 & 14 \\
\hline $\begin{array}{l}\text { Homaxinella } \\
\text { balfourensis }\end{array}$ & Winter & - & $70.7^{\star}$ & 2.0 & 15 \\
\hline $\begin{array}{l}\text { Isodictya } \\
\text { kerguelenensis }\end{array}$ & Winter & 31.07 .06 & 84.9 & 1.2 & 12 \\
\hline Mycale acerata & Summer & 12.03 .07 & 84.3 & & 1 \\
\hline Mycale acerata & Winter & - & 88.1 & 0.6 & 19 \\
\hline Phorbas sp. & Summer & 12.03 .07 & 73.2 & 0.2 & 2 \\
\hline Phorbas sp. & Winter & 31.07 .06 & 67.4 & 5.3 & 7 \\
\hline $\begin{array}{l}\text { Sphaerotylus } \\
\text { antarcticus }\end{array}$ & Summer & 31.01 .07 & $94.8^{*}$ & 0.4 & 13 \\
\hline $\begin{array}{l}\text { Sphaerotylus } \\
\text { antarcticus }\end{array}$ & Winter & 06.06 .06 & $71.6^{\star}$ & 0.5 & 30 \\
\hline Suberites sp. & Summer & 15.02 .07 & $83.0 \mathrm{a}$ & 0.5 & 13 \\
\hline Suberites sp. & Summer & 12.03 .07 & $80.4 \mathrm{~b}$ & 0.4 & 12 \\
\hline Suberites sp. & Winter & - & $76.3^{*}$ & 0.3 & 27 \\
\hline
\end{tabular}

Within each species * indicates a significant difference between seasons (ANOVA, $p<$ $0.05)$ and within each species, seasonal $\%$ water contents with the same letter, were not significantly different (Tukey tests, $P<0.05$ ).

Ash content of dried tissue of Antarctic sponges varied widely between species, ranging from 16 to $73 \%$ (Table 2). Ash content only varied seasonally in five species, with four species exhibiting lower ash content in winter, A. antarctica $\left[F_{(1,13)}=37.7\right.$, $P<0.01]$, C. arcuarius $\left[F_{(1,19)}=156, P<0.01\right]$, S. antarcticus $\left[F_{(1,42)}=7.6, P<0.01\right]$, and Suberites sp. $\left[F_{(1,51)}=4.4\right.$, $P<0.05]$. One species, Clathria nidificata $\left[F_{(1,36)}=8.7\right.$, $P<0.06]$, had a higher ash content in winter. The three species for which sequential samples were taken throughout the winter showed either a reduction (Suberites spp. and D. antarctica), or an increase ( $S$. antarctica) in ash content as winter progressed (Table 1).

Oxygen consumption was highly variable, ranging from 1 to $12 \mu \mathrm{mol} \mathrm{O} \mathrm{O}_{2} \mathrm{gAFDM}^{-1} \cdot \mathrm{h}^{-1}$ (Figure 2) between species $\left[F_{(3,141)}=50.6, P<0.01\right]$ with season having a significant effect on metabolic rate in all four species $\left[F_{(1,141)}=141, P<0.01\right]$ for which there were both summer and winter measurements. There was a significant interaction between species and season $\left[F_{(3,141)}=59.6, P<0.01\right]$ with oxygen consumption being higher in summer in three species $(T>5.1, P<0.01)$, however, $D$. antarctica had a higher oxygen consumption in winter $(T=$ 4.4, $P<0.01)$.

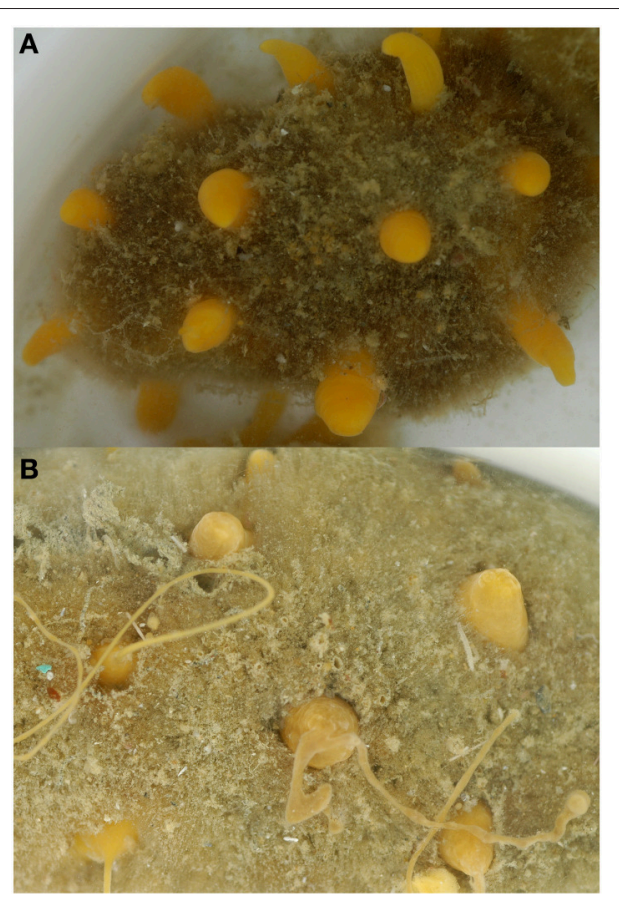

FIGURE 1 | Sphaerotylus antarcticus in (A) summer and (B) winter. In summer the oscular papillae were generally short and wide and in winter some of the oscular papillae elongated and narrowed and grew long filaments with asexual buds along their length.

In summer $C$. nidificata produced significantly more ammonia $(T>9.0, P<0.01)$, whereas Suberites sp. produced significantly less ammonia $(T>10.5, P<0.01)$ than other sponges species investigated (Figure 3). Suberites sp. exhibited the only seasonal difference in ammonia production, with an increased production in winter $(T=10.9, P<0.01)$.

The highest urea production was measured in $C$. nidificata $(T>11.4, P>0.01)$ and $S$. antarcticus $(T>21.1, P<0.01)$ in summer (Figure 4). D. antarctica $(T=5.6, P<0.01)$ produced more urea in summer than winter, whereas Suberites sp. $(T=2.5$, $P=0.17$ ) had no seasonal difference in urea production.

There was an overall significant difference in $\mathrm{O}: \mathrm{N}$ ratio between species $\left[F_{(3,107)}=70.5, P<0.01\right]$ and between seasons $\left[F_{(1,107)}=12.0, p<0.01\right]$. C. nidificata had a significantly lower O:N ratio $(T>11.6, P<0.01$; Figure 5) than the other species. Two species were measured in both summer and winter and exhibited different seasonal responses [interaction term, $\left.F_{(1,69)}=13.0, P<0.01\right]$. D. antarctica had a higher O:N ratio in winter whereas Suberites sp. had a lower O:N ratio in winter (Figure 5).

Only one species had significant differences in proximate composition between seasons (Table 3). H. balfourensis had higher proportions of $\mathrm{C}, \mathrm{H}$, and $\mathrm{N}$ in dried tissues in winter than summer $\left[F_{(1,18)}=19.5, P<0.01\right]$.

\section{DISCUSSION}

Antarctic sponges clearly have the ability to grow, reproduce and thrive in the coldest marine environments, and their contrasting 
TABLE 2 | The \% ash content of dried tissues of sponge species in summer and winter.

\begin{tabular}{|c|c|c|c|c|c|}
\hline Species & Season & Date & $\%$ Ash & SE & $N$ \\
\hline Axinella antarctica & Summer & 12.03 .07 & $66.4^{*}$ & 3.7 & 3 \\
\hline Axinella antarctica & Winter & 31.07 .06 & $28.1^{\star}$ & 2.9 & 12 \\
\hline Calyx arcuarius & Summer & 06.02 .07 & $66.2^{*}$ & 1.1 & 8 \\
\hline Calyx arcuarius & Winter & 31.07 .06 & $35.5^{\star}$ & 1.8 & 12 \\
\hline Clathria nidificata & Summer & 20.02 .07 & $65.5^{\star}$ & 1.6 & 11 \\
\hline Clathria nidificata & Winter & 21.07 .06 & $69.6^{\star}$ & 0.6 & 26 \\
\hline Dendrilla antarctica & Summer & 09.02.07 & $23.5 a$ & 1.5 & 12 \\
\hline Dendrilla antarctica & Summer & 10.02 .07 & $20.2 b$ & 0.6 & 12 \\
\hline Dendrilla antarctica & Summer & 12.03 .07 & 19.5ab & 1.0 & 12 \\
\hline Dendrilla antarctica & Winter & - & $26.2 \mathrm{a}$ & 2.2 & 10 \\
\hline Dendrilla antarctica & Winter & 09.07 .06 & 21.3ab & 2.0 & 10 \\
\hline Dendrilla antarctica & Winter & 19.07.06 & $16.4 b$ & 1.5 & 3 \\
\hline Hemigellius sp. & Winter & 06.06 .06 & $68.0 a$ & 1.3 & 9 \\
\hline Hemigellius sp. & Winter & 31.07 .06 & $41.4 b$ & 2.6 & 3 \\
\hline Homaxinella balfourensis & Summer & 06.02 .07 & 52.1 & 2.7 & 14 \\
\hline Homaxinella balfourensis & Winter & 06.06 .06 & 53.4 & 12.2 & 3 \\
\hline Isodictya kerguelenensis & Winter & 31.07 .06 & $38.0 \mathrm{a}$ & 2.4 & 12 \\
\hline Mycale acerata & Summer & 12.03 .07 & 72.5 & & 1 \\
\hline Mycale acerata & Winter & - & $64.6 a$ & 1.6 & 10 \\
\hline Mycale acerata & Winter & 31.07 .06 & $35.9 b$ & 2.5 & 9 \\
\hline Phorbas sp. & Summer & 12.03 .07 & 65.5 & 2.2 & 2 \\
\hline Phorbas sp. & Winter & 31.07 .06 & 49.7 & 3.4 & 7 \\
\hline Sphaerotylus antarcticus & Summer & 31.01 .07 & $71.3^{\star}$ & 1.4 & 13 \\
\hline Sphaerotylus antarcticus & Winter & 26.04 .06 & $64.3 b$ & 0.9 & 10 \\
\hline Sphaerotylus antarcticus & Winter & 09.05 .06 & $67.1 \mathrm{ab}$ & 1.7 & 10 \\
\hline Sphaerotylus antarcticus & Winter & 06.06 .06 & $70.6 a b$ & 1.6 & 3 \\
\hline Sphaerotylus antarcticus & Winter & 19.07.06 & $69.5 a$ & 1.5 & 7 \\
\hline Suberites sp. & Summer & 1.1 .00 & $47.7^{\star}$ & 1.1 & 25 \\
\hline Suberites sp. & Winter & 25.04 .06 & $50.5 a$ & 0.0 & 5 \\
\hline Suberites sp. & Winter & 17.05 .06 & $50.5 a$ & 1.1 & 10 \\
\hline Suberites sp. & Winter & 06.06 .06 & $52.9 a$ & 3.6 & 3 \\
\hline Suberites sp. & Winter & 31.07 .06 & $23.7 b$ & 1.7 & 9 \\
\hline
\end{tabular}

Within each species * indicates a significant difference between seasons (ANOVA, $p<$ $0.05)$ and within each species, seasonal \% ash contents with the same letter, were not significantly different (Tukey tests, $P<0.05$ ). SE, standard error of mean; $N$, sample size.

physiological strategies may be key to their success in the face of extreme changes in food availability (McClintock et al., 2005). Sponges can thrive under ice-shelves, hundreds of kilometers from open water utilizing horizontally advected food sources (Riddle et al., 2007), whilst an increasing number of sponge species are being found with the capacity to respond rapidly to changes in primary productivity and new habitat availability (Gutt and Piepenburg, 2003; Dayton et al., 2013; Fillinger et al., 2013). Although this study could only measure the physiology of the whole sponge community the seasonal changes measured in Antarctic shallow water demosponges were amongst the highest measured for any taxonomic group, we found even greater between-species variation in physiological strategy, with little consistent seasonal pattern to these respones (Table 4). Comparisons of the physiological patterns of D. antarctica and

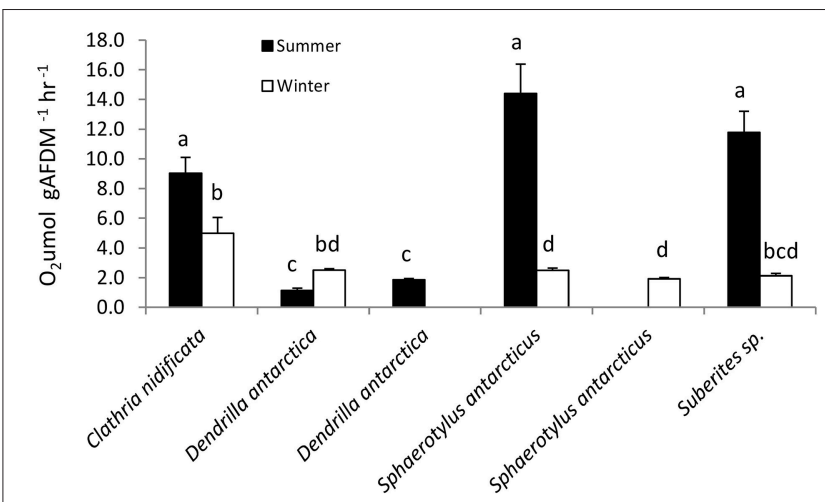

FIGURE 2 | Metabolic rate of sponge species in summer and winter. Values of oxygen consumption with same letter are not significantly different (Tukey tests, $P<0.05$ )

Suberites sp. highlight the different seasonal strategies. Suberites sp. increased metabolic rate in summer and the higher $\mathrm{O}: \mathrm{N}$ ratio indicates that the metabolic substrate had a higher proportion of carbohydrate and lipid in their diet in summer and a lower organic mass. D. antarctica conversely had a lower metabolic rate in summer, a much lower $\mathrm{O}: \mathrm{N}$ ratio, indicating a higher proportion of protein in the metabolic substrate, but this did not result in a change in AFDM. The increase in winter metabolic rate of $D$. antarctica, in an environment with virtually no primary productivity in the water column during the winter months suggests that they are relying on other sources of nutrition. This ability to utilize alternative sources of nutrition, may be the reason that sponges are able to successfully colonize such a wide range of environments.

In this study, season had a significant effect on oxygen consumption in all four species studied. The winter to summer change ranged from $\mathrm{x} 0.8$ for Clathra (Axosuberites) nidificata to $\mathrm{x} 5.5$ for Suberites sp. and $\mathrm{x} 5.8$ for $S$. antarcticus. Seasonal changes in oxygen consumption have previously been evaluated for 17 species of Antarctic marine ectotherms from eight phyla (Figure 6). These changes ranged from 0.9 for the bryozoan Camptoplites bicornis to 3.4 for the bryozoan Isoseculiflustra tenuis. The sponge communities studied here thus have two of the largest recorded seasonal changes in metabolism and the range of responses in sponges is greater than that for all other phyla that have been reported to date (Figure 6). Seasonal factorial increase in metabolic rate of aquatic marine invertebrates from non-polar environments ranged from 1.3 to 5.8 [Supplementary Table 1 but with the exception of Argopecten irradians with a factorial rise of 16.7 associated with a large increase in gonad production (Bricelj et al., 1987)]. This may, on the face of it seem a surprising result, as sponges are a sessile suspension feeding group, and low activity taxa usually have poor capacities to raise metabolic rates and hence low aerobic scopes (Peck, 1998). The reason for this unexpected phenotypic plasticity may lie in the interaction between the sponge tissues and a species specific microbial community (Weisz et al., 2008), which likely amplifies the seasonal variation in metabolism. 


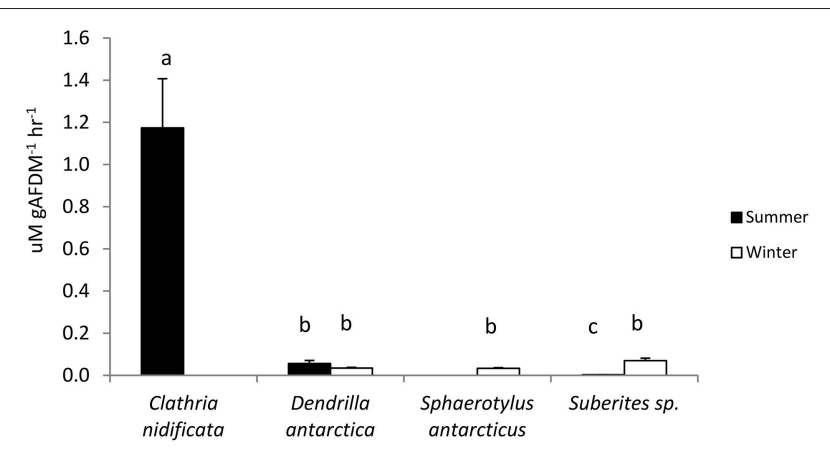

FIGURE 3 | Ammonia production by sponges in summer and winter. Values of ammonia production with the same letter are not significantly different (Tukey tests, $P<0.05$ ).

This study was only able to measure the integrated physiological response of the sponge community and it is possible that different components might have varied in their temporal metabolic responses. Whilst this study will almost certainly miss some of the temporal dynamics within the community, evolution is expected to act on the community as a whole and isolated symbionts are unlikely to have the same physiology when separated from their host. Sponge community metabolic rates vary depending on sponge activity (Hoffmann et al., 2008). However, Hoffmann et al. (2008) only attributed a three fold difference in metabolic rate to activity, whereas, in the current study metabolic rate varied more than 10 fold between species, a similar level of variation to that found previously for polar sponge species, $1.5-22.1 \mu \mathrm{mol} \mathrm{O} \mathrm{gAFDM}^{-1} \mathrm{~h}^{-1}$ (Witte and Graf, 1996; Kowalke, 2000; Gatti et al., 2002). An analysis of literature values for metabolic rates of sponges across latitudes showed that there was no correlation between oxygen consumption and measurement temperature $\left[F_{(1,27)}=0.57\right.$, $p=0.46$; Supplementary Table 1]. This is a very unusual result, as metabolic rates of ectotherms is almost always correlated with temperature (Brown et al., 2004). This provides further evidence that the variability in metabolic rate of sponges likely reflects the wide variety of physiological strategies utilized by sponges and the complexity of their biomes. High levels of metabolic plasticity are also found in other taxa that utilize different degrees of symbiotic energy supply. For example, zooxanthellate species of scleractinian coral have much lower ammonia excretion [51-192 (mg-at $\mathrm{N})^{-1} \mathrm{~h}^{-1}$ ] than non zooxanthellate species [257-632 $\left.(\mathrm{mg} \text {-at } \mathrm{N})^{-1} \mathrm{~h}^{-1}\right]$, possibly indicating that nitrogen is providing nutritional support for zooxanthellae and not being excreted to the water column (Szmant et al., 1990).

The range of rates of nitrogen excretion measured in Antarctic sponges in the current study $\left(1-570 \mathrm{nmol} \mathrm{g}^{-1}\right.$ dry wt $\mathrm{h}^{-1}$ ) was lower than the range reported for nitrogen excretion of Mediterranean, $18-1325 \mathrm{nmol} \mathrm{g}^{-1}$ dry wt $\mathrm{h}^{-1}$ (Jimenez and Ribes, 2007; Bayer et al., 2008), and tropical sponges, 30-2650 $\mathrm{nmol} \mathrm{g}^{-1}$ dry wt $\mathrm{h}^{-1}$; (Diaz and Ward, 1997). Whilst the lowest reported values for Antarctic species were 18-30 times lower than those from warmer regions, the highest values were only 2.5-4.8 times lower than the highest elsewhere, which

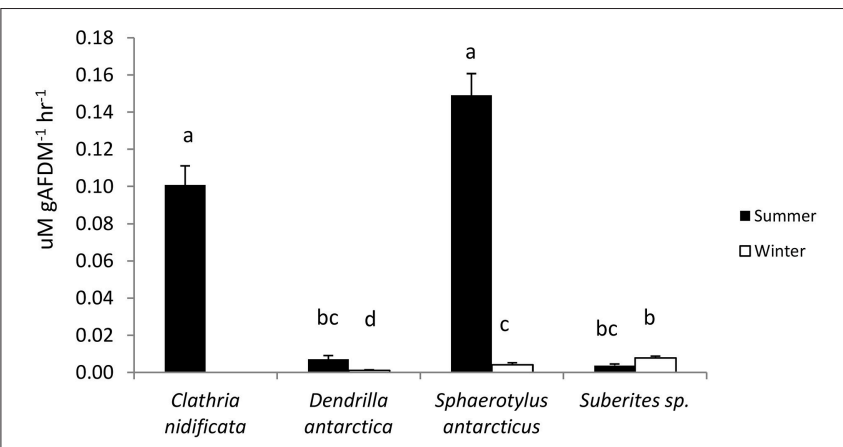

FIGURE 4 | Urea production by sponges in summer and winter. Values of urea production with the same letter are not significantly different (Tukey tests, $P<0.05)$.

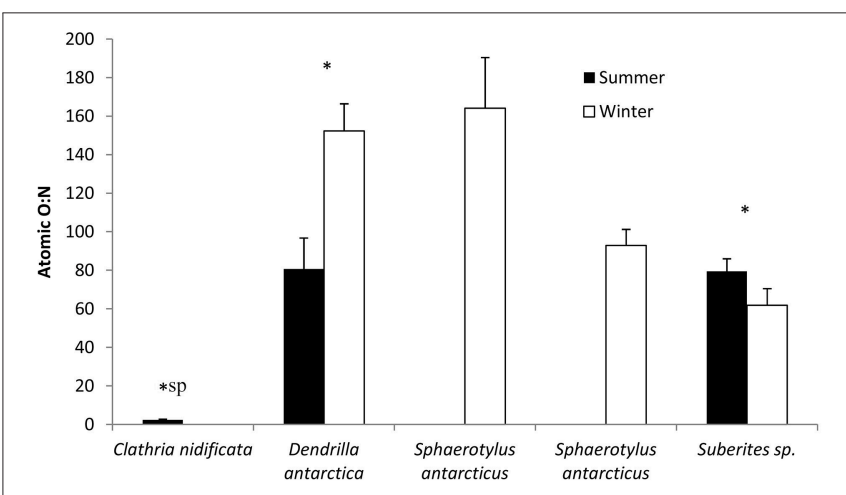

FIGURE 5 | O:N ratio of sponges in summer and winter. * $s p$ indicates a significant difference between species (ANOVA, $P<0.05$ ). *Indicates a signficant within species difference between seasons (ANOVA, $p<0.05$ ).

suggests that not only is protein metabolism slower in Antarctic species, but the between species range is also greater. Whilst nitrogen excretion rates are seasonal in sponges from other regions (Bayer et al., 2008) some of this variation is very likely due to nitrification by bacteria within the sponge biome (Radax, 2011) which could contribute to the mixed seasonal nitrogen excretion responses measured in the current study. In the two species where data were collected in both summer and winter (Figure 3) one had higher ammonia excretion rates in summer (D. antarctica), whilst the other was higher in winter (Suberites sp.). There was also a mixed seasonal response of ammonia excretion of Antarctic marine secondary consumers (Obermüller et al., 2010) which ranged from no change to a seaonal factorial change of 13 . This was a greater variability than literature values for a range of species from other environments which were consistently higher in summer (2-11; Supplementary Material, Table 1).

Urea production is not frequently measured in studies of seasonal metabolism. Here nitrogen excretion as urea ranged from $0.1 \mu \mathrm{MgAFDM}^{-1} \mathrm{~h}^{-1}$ for D. antarctica in winter, to $15 \mu \mathrm{M}$ gAFDM $^{-1} \mathrm{~h}^{-1}$ for $S$. antarcticus in summer, generally more than an order of magnitude lower than ammonia production, confirming demosponges as being ammonotelic. Similar to the seasonal changes in oxygen consumption, sponge species showed 
TABLE 3 | Proximate composition, total \% Carbon, Hydrogen, and Nitrogen content, of dried tissue of sponge species in summer and winter.

\begin{tabular}{|c|c|c|c|c|c|c|c|}
\hline Species & Season & \% Carbon & $N$ & $\%$ Hydrogen & $N$ & $\%$ Nitrogen & $N$ \\
\hline Clathria nidificata & Summer & $12.6 \pm 0.9$ & 10 & $2.3 \pm 0.1$ & 10 & $2.5 \pm 0.2$ & 10 \\
\hline Clathria nidificata & Winter & $11.5 \pm 0.5$ & 10 & $2.2 \pm 0.1$ & 10 & $2.3 \pm 0.1$ & 10 \\
\hline Dendrilla antarctica & Summer & $41.4 \pm 2.3$ & 10 & $6.0 \pm 0.3$ & 10 & $9.6 \pm 0.6$ & 10 \\
\hline Dendrilla antarctica & Winter & $39.8 \pm 0.6$ & 9 & $5.7 \pm 0.1$ & 9 & $8.9 \pm 0.2$ & 9 \\
\hline Homaxinella balfourensis & Summer & $13.2 \pm 1.2 \mathrm{a}$ & 10 & $2.3 \pm 0.1 \mathrm{a}$ & 10 & $3.3 \pm 0.2 a$ & 10 \\
\hline Homaxinella balfourensis & Winter & $23.5 \pm 2.0 b$ & 9 & $3.7 \pm 0.3 b$ & 9 & $5.2 \pm 0.4 b$ & 9 \\
\hline Suberites sp. & Summer & $23.5 \pm 0.9$ & 9 & $3.6 \pm 0.1$ & 9 & $4.7 \pm 0.1$ & 9 \\
\hline Suberites sp. & Winter & $23.4 \pm 0.9$ & 9 & $3.6 \pm 0.1$ & 9 & $4.7 \pm 0.2$ & 9 \\
\hline Sphaerotylus antarcticus & Summer & $12.2 \pm 1.3$ & 9 & $2.2 \pm 0.2$ & 9 & $2.8 \pm 0.3$ & 9 \\
\hline Sphaerotylus antarcticus & Winter & $9.0 \pm 0.8$ & 7 & $1.9 \pm 0.1$ & 7 & $2.3 \pm 0.2$ & 7 \\
\hline
\end{tabular}

Mean \pm sem. Within each species, seasonal $\% \mathrm{C}, \mathrm{H}$, and $\mathrm{N}$ values with the same letters are not significantly different (Tukey tests, $P<0.05)$. $N=$ sample size.

a high plasticity of seasonal responses ranging from a $50 \%$ lower urea production in summer than winter (Suberites sp.) to more than a $x 35$ increase in summer over winter in S. antarcticus.

$\mathrm{O}: \mathrm{N}$ ratios in the sponge communities studied here varied from 2.5 in C. nidificata to two species with values over $150, S$. antarcticus and $D$. antarctica. The low values indicate C. nidificata uses protein to fuel its metabolic costs, whereas the values over 150 indicate the metabolic substrate was almost all carbohydrate and lipids. The species with intermediate values (Suberites sp.) was using a mixture of protein and non protein substrates, with O:N ratios between 60 and 80, still indicating carbohydrate and lipid accounted for a much larger proportion of substrate than protein. The seasonal factorial change in $\mathrm{O}: \mathrm{N}$ ratio by Antarctic sponges (0.5-1.3) was within the range recorded for other Antarctic marine ectotherms (0.1-5.6; Supplementary Material, Table 1).

$\mathrm{CHN}$ values obtained for sponges in the current study were at the lower end of those recorded in marine ectotherms (Barbarino and Lourenco, 2009; Obermüller et al., 2013). The range of values, $2-10 \%$ nitrogen for sponges in this study, encompasses the $6 \%$ nitrogen found in other sponges, such as Hymeniacidon heliphila (Barbarino and Lourenco, 2009) and Spongilla lacustris (Sandjensen and Pedersen, 1994). S. lacustris also had a carbon content $(30 \%)$ within the range of those found in the current study (9-41\%). In the study of Obermüller et al. (2013) the lowest overall $\mathrm{CHN}$ values for Antarctic marine invertebrates were found in the nudibranch, Doris kerguelenensis $(28-33 \%$ carbon, 4-5\% hydrogen and 6-8\% nitrogen), whose low values were hypothesized to be a result of its obligate sponge diet. The increase in $\mathrm{CHN}$ content in winter $H$. balfourensis is most likely due to the production of reproductive tissue during this period.

The seasonal difference in phytoplankton availability in the Southern Ocean is amongst the greatest of any ocean (Venables et al., 2013). For many months, phytoplankton standing stock in the water column is very low for suspension feeders, such as sponges. (Barnes and Clarke, 1995). This seasonal variation in phytoplankton productivity has been reported to influence sponge populations and morphology, even in the deep sea (Kahn et al., 2012). The wide range of potential food sources that can be utilized by sponges (Hadas et al., 2009; Perea-Blázquez
TABLE 4 | Summary of seasonal differences in physiological metrics for Clathria nidificata, Dendrilla antarcticus, Sphaerotylus antarcticus, and Suberites sp.

\begin{tabular}{lllll}
\hline Species & $\begin{array}{l}\text { Clathria } \\
\text { nidificata }\end{array}$ & $\begin{array}{l}\text { Dendrilla } \\
\text { antarctica }\end{array}$ & $\begin{array}{l}\text { Sphaerotylus } \\
\text { antarcticus }\end{array}$ & $\begin{array}{l}\text { Suberites } \\
\text { sp. }\end{array}$ \\
\hline Metabolic rate & $\uparrow$ & $\downarrow$ & $\uparrow$ & $\uparrow$ \\
Ammonia & & $=$ & & $\downarrow$ \\
Urea & $\uparrow$ & $\uparrow$ & $\downarrow$ \\
O:N & & $\downarrow$ & & $\uparrow$ \\
CHN & $=$ & $=$ & $=$ & $=$ \\
AFDM & $\downarrow$ & $=$ & $\uparrow$ & $\downarrow$
\end{tabular}

$\uparrow$ Indicates higher in summer, $\downarrow$ indicates lower in summer, = indicates no significant change.

et al., 2013a) may lead to some food being available across seasons, at least for some sponge species. In the current study, the most substantial seasonal difference in morphology was the increase in relative ash content (four out of five species) and the increase in organic content of $H$. balfourensis in winter. The change in $H$. balfourensis coincided with a change in morphology to a more twig-like growth form. This sponge is well-known in the Antarctic as a pioneer species, settling and growing rapidly in ice-scour regions on the shelf (Dayton, 1989; Dayton et al., 2013). Dietary experiments have found that several Antarctic slow-growing sponges species (including S. antarcticus) are specialist picoplankton consumers, which includes freeliving pelagic bacteria, thereby allowing these sponges to feed all year, partially buffering themselves, and their surrounding ecosystems from the extreme Antarctic seasonality (Thurber, 2007). However, Thurber (2007) found that H. balfourensis specialized in comsuming larger sized plankton, which may explain its observed fast growth rates during periods of reduced upwelling, while increased upwelling has been found to lead to population declines of this species around the Antarctic (Dayton, 1989).

Morphological plasticity is common in demosponges, as they have a leuconoid cell structure, which is believed to permit great diversity of shape, allowing plastic morphological responses 


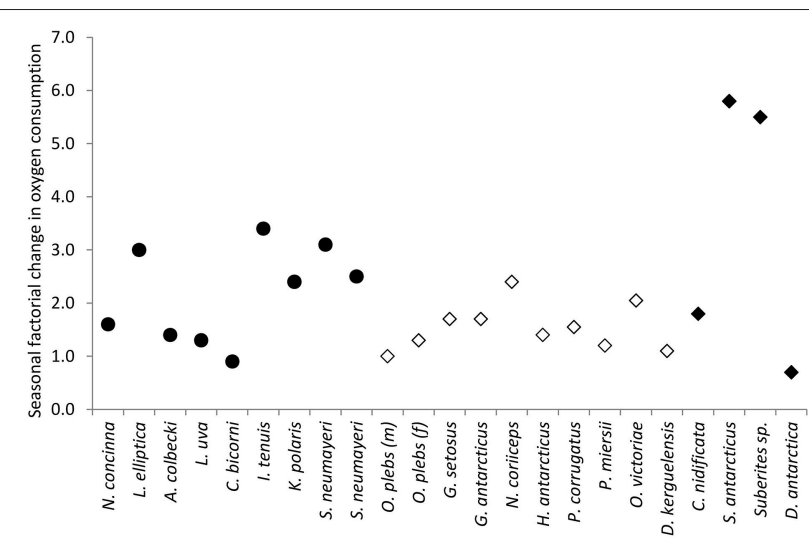

FIGURE 6 | Factorial seasonal changes in oxygen consumption, modified from Obermüller et al. (2010). Filled circles are polar herbivores: Nacella concinna (Fraser et al., 2002a), Laternula elliptica (Brockington and Peck, 2001), Adamussium colbecki (Heilmayer and Brey, 2003), Liothyrella uva (Peck et al., 1987, 1997) Camptoplites bicornis, Isoseculiflustra tenuis, Kymella polaris (Barnes and Peck, 2005), Sterchinus neumayeri -1997 and 1998 (Brockington and Peck, 2001). Open diamonds are polar carnivores and scavengers: Orchomene plebs (m, male; f, female) (Rakusa-Suszczewski, 1982), Gammarus setosus (Weslawski and Opalinski, 1997), Glyptonotus antarcticus (Rakusa-Suszczewski, 1982), Notothenia coriiceps (Campbell et al., 2008), Harpagifer antarcticus, Parborlasia corregatus, Paracerodocus miersii, Ophionotus victoriae, and Doris Kerguelensis (Obermüller et al., 2010). Filled diamonds are sponges from the current study.

to changes in environmental conditions and productivity (Bergquist, 1978). In the current study, development of both sexual and asexual progagules was also recorded in other Antarctic demosponges during winter. Embryo development of polar ectotherms is slowed considerably and may take as long as 2 years (Pörtner et al., 2000). So the seasonal changes in the morphology of Antarctic demosponges recorded here, most likely corresponded to the period of propogule maturation and is unlikely to have been a direct response to reduced primary productivity. It is possible that the sponge biome buffers the lack of external nutrition during winter.

The "life in the slow lane" paradigm for polar sponges is perhaps most evident in their energetics. The lowest recorded oxygen consumption of polar marine invertebrates has been found in sponges, brachiopods, and bryozoans (Barnes and Peck, 2005). Many ectotherms living in the near-constant cold of the Southern Ocean have very low physiological capacities and globally, the life history of Antarctic sponges has long been considered to be amongst one of the slowest (Gutt and Koltun, 1995; Barnes, 2013). However, the great phenotypic variation

\section{REFERENCES}

Baldwin, E. (1967). Dynamic Aspects of Biochemistry. Cambridge: Cambridge University Press.

Barbarino, E., and Lourenco, S. O. (2009). Comparison of $\mathrm{CHN}$ analysis and Hach acid digestion to quantify total nitrogen in marine organisms. Limnol. Oceanogr. Methods 7, 751-760. doi: 10.4319/lom.2009.7.751 demonstrated by demosponges in the current study suggests that there are exceptions to the paradigm, which may explain why sponges are highly abundant, speciose, and ubiquitous. The range of temporal physiological strategies found in sponges could be key to their successful colonization of such a broad range of habitats.

Recent evidence has shown that rapid growth can occur in some species of sponge (Dayton et al., 2013), as has also been demonstrated for bryozoans (Barnes, 2013), particularly in response to increased phytoplankton availability. The collapse of ice shelves (Peck et al., 2010; Fillinger et al., 2013) and the reduction in sea-ice (Barnes et al., 2014) have altered phytoplankton dynamics (Venables et al., 2013) opening up new habitats for sponges (Fillinger et al., 2013). Sponges can respond rapidly to spatio-temporal changes in sea ice concentration; with major sponge settlement events occurring in response to associated changes in phytoplankton dynamics after decades of no noticeable growth or recruitment (Dayton et al., 2013). Similar rapid recruitment and growth of glass sponges was recorded after the collapse of the Larsen A-B ice shelves (Fillinger et al., 2013). Emerging evidence, therefore, suggests that some Antarctic sponges are better able to buffer seasonal food shortages and can respond rapidly to environmental change, potentially leading to an important new source of carbon drawdown and increased bentho-pelagic coupling. These ecological observations of great variation in the ecology of Antarctic sponge species are similar to variations seen elsewhere in the world, and this may be a reflection of their very large interspecific phenotypic plasticity of metabolic physiology in sponges, which is likely a key component of their global success.

\section{ACKNOWLEDGMENTS}

This work was supported by NERC core funding to the British Antarctic Survey's Adaptation and Physiology work package within the Ecosystems program. None of the authors have a financial conflict arising from this work. We thank the marine team and station support at Rothera Research station. We also thank Manuela Truebano and Paul Geissler who prepared and analyzed the $\mathrm{CHN}$ samples.

\section{SUPPLEMENTARY MATERIAL}

The Supplementary Material for this article can be found online at: http://journal.frontiersin.org/article/10.3389/fevo. 2015.00157 
Barnes, D. K. A., and Peck, L. S. (2005). Extremes of metabolic strategy in Antarctic Bryozoa. Mar. Biol. 147, 979-988. doi: 10.1007/s00227-005-1628-3

Barthel, D. (1995). Tissue composition of sponges from the Weddell Sea, Antarctica- not much meat on the bones. Mar. Ecol. Prog. Ser. 123, 149-153. doi: $10.3354 /$ meps123149

Bayer, K., Schmitt, S., and Hentschel, U. (2008). Physiology, phylogeny and in situ evidence for bacterial and archaeal nitrifiers in the marine sponge Aplysina aerophoba. Environ. Microbiol. 10, 2942-2955. doi: 10.1111/j.14622920.2008.01582.x

Bergquist, P. R. (1978). Sponges. Berkeley, CA: University of California Press.

Boury-Esnault, N., and Ruetzler, K. (1997). Thesaurus of sponge morphology. Smithsonian Contributions to Zoology. Washington, DC: Smithsonian Institution.

Bricelj, V. M., Epp, J., and Malouf, R. E. (1987). Comparative physiology of young and old cohorts of bay scallop Argopecten irradians irradians (Lamarck) mortality, growth, and oxygen consumption. J. Exp. Mar. Biol. Ecol. 112, 73-91. doi: 10.1016/0022-0981(87)90110-9

Brockington, S., and Peck, L. S. (2001). Seasonality of respiration and ammonium excretion in the Antarctic echinoid Sterechinus neumayeri. Mar. Ecol. Prog. Ser. 219, 159-168. doi: 10.3354/meps219159

Brown, J. H., Gillooly, J. F., Allen, A. P., Savage, V. M., and West, G. B. (2004). Toward a metabolic theory of ecology. Ecology 85, 1771-1789. doi: 10.1890/039000

Campbell, H. A., Fraser, K. P. P., Bishop, C. M., Peck, L. S., and Egginton, S. (2008). Hibernation in an Antarctic fish: on ice for winter. PLoS ONE 3:e1743. doi: 10.1371/journal.pone. 0001743

Clarke, A. (1988). Seasonality in the Antarctic marine environment. Comp. Biochem. Physiol. B Biochem. Mol. Biol. 90, 461-473. doi: 10.1016/03050491(88)90285-4

Clarke, A., Holmes, L. J., and White, M. G. (1988). The annual cycle of temperature, chlorophyll and major nutrients at Signy Island, South Orkney Islands, 1969-82. Br. Antarctic Survey Bull. 80, 65-86.

Clarke, A., Prothero-Thomas, E., and Whitehouse, M. J. (1994). Nitrogen excretion in the Antarctic limpet Nacella concinna (Strebel, 1908). J. Molluscan Stud. 60, 141-147. doi: 10.1093/mollus/60.2.141

Cocito, S. (2004). Bioconstruction and biodiversity: their mutual influence. Sci. Mar. 68, 137-144. doi: 10.3989/scimar.2004.68s1137

Coma, R., Ribes, M., Gili, J. M., and Zabala, M. (1998). An energetic approach to the study of life-history traits of two modular colonial benthic invertebrates. Mar. Ecol. Prog. Ser. 162, 89-103. doi: 10.3354/meps162089

Dayton, P. K. (1989). Interdecadal variation in an antarctic sponge and its predators from oceanographic climate shifts. Science 245, 1484-1486. doi: 10.1126/science.245.4925.1484

Dayton, P. K., Robillia, G. A., Paine, R. T., and Dayton, L. B. (1974). Biological accomodation in benthic community at McMurdo Sound, Antarctica. Ecol. Monogr. 44, 105-128. doi: 10.2307/1942321

Dayton, P. K., Kim, S., Jarrell, S. C., Oliver, J. S., Hammerstrom, K., Fisher, J. L., et al. (2013). Recruitment, growth and mortality of an antarctic hexactinellid sponge, Anoxycalyx joubini. PLoS ONE 8:e56939. doi: 10.1371/journal.pone.0056939

Dayton, P. K., Robilliard, G. A., and Paine, R. T. (1970). "Benthic faunal zonation as a result of anchor ice at McMurdo Sound, Antarctica," in Antarctic Ecology, Vol. 1, ed M. W. Holdgate, (London: Academic Press), 244-258.

Degobbis, D. (1973). Storage of seawater samples for ammonia determination. Limnol. Oceanogr. 18, 146-150. doi: 10.4319/lo.1973.18.1.0146

Diaz, M. C., and Rutzler, K. (2001). Sponges: an essential component of Caribbean coral reefs. Bull. Mar. Sci. 69, 535-546.

Diaz, M. C., and Ward, B. B. (1997). Sponge-mediated nitrification in tropical benthic communities. Mar. Ecol. Prog. Ser. 156, 97-107. doi: 10.3354/ meps 156097

Erwin, P. M., Pita, L., López-Legentil, S., and Turon, X. (2012). Stability of sponge-associated bacteria over large seasonal shifts in temperature and irradiance. Appl. Environ. Microbiol. 78, 7358-7368. doi: 10.1128/AEM. 02035-12

Fan, T. Y., and Dai, C. F. (1999). Reproductive plasticity in the reef coral Echinopora lamellosa. Mar. Ecol. Prog. Ser. 190, 297-301. doi: $10.3354 /$ meps 190297
Fenchel, T. (1990). Adaptive significance of polymorphic life-cylces in protozoa - responses to starvation and refeeding in 2 species of marine cilliates. J. Exp. Mar. Biol. Ecol. 136, 159-177. doi: 10.1016/0022-0981(90)90159-A

Fillinger, L., Janussen, D., Lundälv, T., and Richter, C. (2013). Rapid glass sponge expansion after climate-induced antarctic ice shelf collapse. Curr. Biol. 23, 1330-1334. doi: 10.1016/j.cub.2013.05.051

Fraser, K. P. P., Clarke, A., and Peck, L. S. (2002a). Feast of famine in Antarctica: seasonal physiology in the limpet Nacella concinna. Mar. Ecol. Prog. Ser. 242, 169-177. doi: 10.3354/meps242169

Fraser, K. P. P., Clarke, A., and Peck, L. S. (2002b). Low-temperature protein metabolism: seasonal changes in protein synthesis and RNA dynamics in the Antarctic limpet Nacella concinna Strebel 1908. J. Exp. Biol. 205, 3077-3086

Fromont, J. (1994). Reproductive development and timing of tropical sponges (order haplosclerida) from the Great Barrier Reef, Australia. Coral Reefs 13, 127-133. doi: 10.1007/BF00300773

Gatti, S. (2002). The role of sponges in high-antarctic carbon and silicon cycling: A modelling approach. Berichte zur Polar- und Meeresforschung 434, 1-124. doi: 10.2312/BZPM_0434_2002

Gatti, S., Brey, T., Muller, W. E. G., Heilmayer, O., and Holst, G. (2002). Oxygen microoptodes: a new tool for oxygen measurements in aquatic animal ecology. Mar. Biol. 140, 1075-1085. doi: 10.1007/s00227-002-0786-9

Gruzov, E. N. (1977). "Seasonal alterations in coastal communities in the Davies Sea," in Adaptations within Ecosystems, ed G. Llano. (Washington, DC: Smithsonian Press), 263-278.

Gutt, J., and Koltun, V. M. (1995). Sponges of the Lazarev and Weddell Sea, Antarctica - explanations for their patchy occurrence. Antarctic Sci. 7, 227-234. doi: $10.1017 /$ S0954102095000320

Gutt, J., and Piepenburg, D. (2003). Scale-dependent impact on diversity of Antarctic benthos caused by grounding of icebergs. Mar. Ecol. Prog. Ser. 253, 77-83. doi: $10.3354 /$ meps 253077

Gutt, J., and Schickan, T. (1998). Epibiotic relationships in the Antarctic benthos. Antarctic Sci. 10, 398-405. doi: 10.1017/S0954102098000480

Hadas, E., Shpigel, M., and Ilan, M. (2009). Particulate organic matter as a food source for a coral reef sponge. J. Exp. Biol. 212, 3643-3650. doi: 10.1242/jeb.027953

Harsha, R. E., Francis, J. C., and Poirrier, M. A. (1983). Water temperature - a factor in the seasonality of 2 fresh water sponge species, Ephydatia fluviatilis and Spongilla alba. Hydrobiologia 102, 145-150. doi: 10.1007/BF00006340

Heilmayer, O., and Brey, T. (2003). Saving by freezing? Metabolic rates of Adamussium colbecki in a latitudinal context. Mar. Biol. 143, 477-484. doi: 10.1007/s00227-003-1079-7

Hoffmann, F. O., Røy, H., Bayer, K., Hentschel, U., Pfannkuchen, M., Brümmer, F., et al. (2008). Oxygen dynamics and transport in the Mediterranean sponge Aplysina aerophoba. Mar. Biol. 153, 1257-1264. doi: 10.1007/s00227-0080905-3

Holmes, R. M., Aminot, A., Kerouel, R., Hooker, B. A., and Peterson, B. J. (1999). A simple and precise method for measuring ammonium in marine and freshwater ecosystems. Can. J. Fish. Aquat. Sci. 56, 1801-1808. doi: 10.1139/f99-128

Hughes, R. N. (1989). A Functional Biology of Clonal Animals. London: Chapman and Hall.

Janussen, D., and Downey, R. V. (2014). “Chapter 5.5; Porifera," in Biogeographic Atlas of the Southern Ocean, eds C. De Broyer, P. Koubbi, H. J. Griffiths, B. Raymond, and C. Udekem D'acoz. (Cambridge: Scientific Committee on Antarctic Research), 94-102.

Jimenez, E., and Ribes, M. (2007). Sponges as a source of dissolved inorganic nitrogen: nitrification mediated by temperate sponges. Limnol. Oceanogr. 52, 948-958. doi: 10.4319/lo.2007.52.3.0948

Kahn, A. S., Ruhl, H. A., and Smith, K. L. Jr. (2012). Temporal changes in deep-sea sponge populations are correlated to changes in surface climate and food supply. Deep Sea Res. Part I Oceanogr. Res. Pap. 70, 36-41. doi: 10.1016/j.dsr.2012.08.001

Kirkpatrick, R. (1907). Preliminary report on the Monaxonellida of the National Antarctic expedition. Ann. Mag. Nat. Hist. 20, 271-291.

Koltun, V. M. (1964). "Sponges of the Antarctic. 1 Tetraxonida and Cornacuspongida," in Biological Reports of the Soviet Antarctic Expedition 
(1955-1958), eds E. P. Pavlovskii, A. P. Andriyashev, and P. V. Ushakov (Akademya Nauk SSSR), 6-133, 443-448.

Kowalke, J. (2000). Ecology and energetics of two Antarctic sponges. J. Exp. Mar. Biol. Ecol. 247, 85-97. doi: 10.1016/S0022-0981(00)00141-6

Mayzaud, P., and Conover, R. J. (1988). O:N atomic ratio as a tool to describe zooplankton metabolism. Mar. Ecol. Prog. Ser. 45, 289-302. doi: 10.3354/meps045289

McClintock, J. B., Amsler, C. D., Baker, B. J., and Van Soest, R. W. M. (2005). Ecology of Antarctic marine sponges: an overview. Integr. Comp. Biol. 45, 359-368. doi: 10.1093/icb/45.2.359

Meredith, M. P., and King, J. C. (2005). Rapid climate change in the ocean west of the Antarctic Peninsula during the second half of the 20th century. Geophys. Res. Lett. 32, L19604. doi: 10.1029/2005GL024042

Meroz-Fine, E., Shefer, S., and Ilan, M. (2005). Changes in morphology and physiology of an East Mediterranean sponge in different habitats. Mar. Biol. 147, 243-250. doi: 10.1007/s00227-004-1532-2

Morley, S. A., Peck, L. S., Miller, A. J., and Pörtner, H. O. (2007). Hypoxia tolerance associated with activity reduction is a key adaptation for Laternula elliptica seasonal energetics. Oecologia 153, 29-36. doi: 10.1007/s00442-0070720-4

Obermüller, B. E., Morley, S. A., Barnes, D. K. A., and Peck, L. S. (2010). Seasonal physiology and ecology of Antarctic marine benthic predators and scavengers. Mar. Ecol. Prog. Ser. 415, 109-126. doi: 10.3354/meps08735

Obermüller, B. E., Truebano, M., Peck, L. S., Eastman, J. T., and Morley, S. A. (2013). Reduced seasonality in elemental CHN composition of Antarctic marine benthic predators and scavengers. J. Exp. Mar. Biol. Ecol. 446, 328-333. doi: 10.1016/j.jembe.2013.06.001

Peck, L. S. (1998). Feeding, metabolism and metabolic scope in Antarctic ectotherms. Soc. Exp. Biol. Semin. Ser. 66, 365-389.

Peck, L. S., Barnes, D. K. A., Cook, A. J., Fleming, A. H., and Clarke, A. (2010). Negative feedback in the cold: ice retreat produces new carbon sinks in Antarctica. Glob. Change Biol. 16, 2614-2623. doi: 10.1111/j.13652486.2009.02071.x

Peck, L. S., Brockington, S., and Brey, T. A. (1997). Growth and metabolism in the Antarctic brachiopod Liothyrella uva. Philos. Trans. R. Soc. Lond. Ser. B Biol. Sci. 352, 851-858. doi: 10.1098/rstb.1997.0065

Peck, L. S., Clarke, A., and Holmes, L. J. (1987). Summer metabolism and seasonal-changes in biochemical-composition of the antarctic brachiopod liothyrella-UVA (Broderip, 1833). J. Exp. Mar. Biol. Ecol. 114, 85-97. doi: 10.1016/0022-0981(87)90142-0

Peck, L. S., Convey, P., and Barnes, D. K. A. (2006). Environmental constraints on life histories in Antarctic ecosystems: tempos, timings and predictability. Biol. Rev. 81, 75-109. doi: 10.1017/S1464793105006871

Perea-Blázquez, A., Davy, S. K., and Bell, J. J. (2013a). Low functional redundancy in sponges as a result of differential picoplankton use. Biol. Bull. 224, 29-34.

Perea-Blazquez, A., Davy, S. K., Magana-Rodriguez, B., and Bell, J. J. (2013b). Temporal variation in food utilisation by three species of temperate demosponge. Mar. Ecol. Prog. Ser. 485, 91-103. doi: 10.3354/meps10316

Pörtner, H. O., Bock, C., and Reipschlager, A. (2000). Modulation of the cost of pHi regulation during metabolic depression: a P-31-NMR study in invertebrate (Sipunculus nudus) isolated muscle. J. Exp. Biol. 203, 2417-2428.

Post, A. L., Hemer, M. A., O’brien, P. E., Roberts, D., and Craven, M. (2007). History of benthic colonisation beneath the Amery Ice Shelf, East Antarctica. Mar. Ecol. Prog. Ser. 344, 29-37. doi: 10.3354/meps06966

Radax, R. (2011). Ammonia-Oxidising Archeae in Marine Cold-Water Sponges. Ph.D. Uinversitat Wien.

Rahmatullah, M., and Boyde, T. R. C. (1980). Improvements in the determination of urea using diacetyl monoxime methods with and without deproteinization. Clin. Chim. Acta 107, 3-9. doi: 10.1016/0009-8981(80)90407-6

Rakusa-Suszczewski, S. (1982). The biology and metabolism of Orchomene plebs (Hurley 1965) (amphipoda, gammaridea) from Mcmurdo Sound, Ross Sea, Antarctic. Polar Biol. 1, 47-54. doi: 10.1007/BF00568754

Riddle, M. J., Craven, M., Goldsworthy, P. M., and Carsey, F. (2007). A diverse benthic assemblage $100 \mathrm{~km}$ from open water under the Amery Ice Shelf, Antarctica. Paleoceanography 22:PA1204. doi: 10.1029/2006PA001327

Ridley, S. O., and Dendy, A. (1886). Preliminary report on the Monaxonida collected by H.M.S. 'Challenger'. Ann. Mag. Nat. Hist. 18, 325-351; 470-493.
Sandjensen, K., and Pedersen, M. F. (1994). Photosynthesis by symbiotic algae in the fresh-water sponge, Spongilla-Lacustris. Limnol. Oceanogr. 39, 551-561. doi: 10.4319/lo.1994.39.3.0551

Szmant, A. M., Ferrer, L. M., and Fitzgerald, L. M. (1990). Nitrogen-excretion and o-n ratios in reef corals - evidence for conservation of nitrogen. Mar. Biol. 104, 119-127. doi: 10.1007/BF01313165

Topsent, E. (1905). Notes sur les Éponges receuillies par le Français dans l'Antarctique. Description d'une Dendrilla nouvelle. Bull. Mus. Hist. Nat. 11, 502-505.

Topsent, E. (1913). Spongiaires de l'Expédition Antarctique Nationale Ecossaise. Trans. R. Soc. Edinb. 49, 579-643.

Thurber, A. R. (2007). Diets of Antarctic sponges: links between the pelagic microbial loop and benthic metazoan food web. Mar. Ecol. Prog. Ser. 351, 77-89. doi: 10.3354/meps07122

Vacelet, E. (1971). The ecology of the sulfate reducing micro flora in a marine environment and in an environment with variable salinity. Tethys 3, 3-10.

Vacelet, J. (1975). Electron microscope study of association between bacteria and sponges of the genus Verongia (Dictyoceratida). J. Microsc. Biol. Cell. 23, 271-288.

Van Soest, R. W. M., Boury-Esnault, N., Vacelet, J., Dohrmann, M., Erpenbeck, D., De Voogd, N. J., et al. (2012). Global diversity of sponges (Porifera). PLoS ONE 7:e35105. doi: 10.1371/journal.pone.0035105

Venables, H. J., Clarke, A., and Meredith, M. P. (2013). Wintertime controls on summer stratification and productivity at the western Antarctic Peninsula. Limnol. Oceanogr. 58, 1035-1047. doi: 10.4319/lo.2013.58.3.1035

Voss, J. (1988). Zoogeography and community analysis of macrozoobenthos of the Weddell Sea Antarctica. Berichte zur Polarforschung 19, 1-145.

Webster, N. S., Negri, A. P., Munro, M. M. H. G., and Battershill, C. N. (2004). Diverse microbial communities inhabit Antarctic sponges. Environ. Microbiol. 6, 288-300. doi: 10.1111/j.1462-2920.2004.00570.x

Weisz, J. B., Hentschel, U., Lindquist, N., and Martens, C. S. (2007). Linking abundance and diversity of sponge-associated microbial communities to metabolic differences in host sponges. Mar. Biol. 152, 475-483. doi: 10.1007/s00227-007-0708-y

Weisz, J. B., Lindquist, N., and Martens, C. S. (2008). Do associated microbial abundances impact marine demosponge pumping rates and tissue densities? Oecologia 155, 367-376. doi: 10.1007/s00442-007-0910-0

Weslawski, M., and Opalinski, K. W. (1997). "Winter and summer metabolic rates of Arctic amphipods. Preliminary results," in Polish Polar Studies, 24th Polar Symposium, ed P. Glowacki. (Warszawa: Institute of Geophysics of the Polish Academy of Sciences, Warszawa), 307-317.

Wilkinson, C. R. (1978). Microbial associations in sponges. 2. Numerical analysis of sponge and water bacterial populations. Mar. Biol. 49, 169-176. doi: 10.1007/BF00387116

Witte, U. (1996). Seasonal reproduction in deep sea sponges - Triggered by vertical particle flux? Mar. Biol. 124, 571-581. doi: 10.1007/BF003 51038

Witte, U., Barthel, D., and Tendal, O. (1994). The reproductive cycle of the sponge Halichondria panicea (1766) and its relationship to temperature and salinity. J. Exp. Mar. Biol. Ecol. 183, 41-52. doi: 10.1016/0022-0981(94) 90155-4

Witte, U., and Graf, G. (1996). Metabolism of deep-sea sponges in the GreenlandNorwegian Sea. J. Exp. Mar. Biol. Ecol. 198, 223-235. doi: 10.1016/00220981(96)00006-8

Wood, C. M. (1993). "Ammonia and urea metabolism and excretion," in The Physiology of Fishes, ed D. H. Evans (Boca Raton, FL: CRC Press), 379-425.

Conflict of Interest Statement: The authors declare that the research was conducted in the absence of any commercial or financial relationships that could be construed as a potential conflict of interest.

Copyright (C) 2016 Morley, Berman, Barnes, de Juan Carbonell, Downey and Peck. This is an open-access article distributed under the terms of the Creative Commons Attribution License (CC BY). The use, distribution or reproduction in other forums is permitted, provided the original author(s) or licensor are credited and that the original publication in this journal is cited, in accordance with accepted academic practice. No use, distribution or reproduction is permitted which does not comply with these terms. 